\title{
The Role of Excellent Center of Science and Technology (IPTEKS) for Building Research Culture and Publication: A Case Study at the Bandung Institute of Technology Indonesia
}

\author{
Ence Surahman \\ Educational Technology \\ State University of Malang, Indonesia \\ ence.surahman.fip@Um.ac.id
}

\begin{abstract}
This article aims to describe the roles of the University's IPTEKS Excellence Center in building the research culture and lecturer publications in universities. The method used is descriptive analysis with data collection techniques through unstructured interviews and analysis of documents in the form of books and reports. This research was carried out in a series of training on the Preparation of Science and Technology Excellence Centers at the Microelectronics Center Institute Technology Bandung. The results of the study carried out were the establishment of a research culture and lecturer publications as a result of the superior center of science and technology with institutional governance and the adequacy of available budgets.
\end{abstract}

Keywords: excelent center for science and technology, research culture and publication

\section{INTRODUCTION}

Higher education institutions as higher education institutions have duties and functions in order to carry out an optimal learning process as an effort to produce graduates with standard qualifications. Many variables must be considered in order to carry out the Tri Darma task of the college. The quality of teaching, research and lecturer service need attention. Lecturers have a very strategic function, role and position in national development in the field of education. All college lecturers innately have fun in the field of teaching, but not yet in the field of research and community service. Thus there is a need for a system, assistance and development of a research and publication culture among lecturers.

Many factors influence the culture of research and publication among lecturers. First factor is personal interest. Each lecturer has a different interest in research. Lecturers who are personally interested in the field of research tend to be actively involved in every opportunity of the research program. Second, the environmental factors of the place of work. The environment has a strategic role in building the work culture of every human resource. An environment that conditions more productive lecturers tends to make lecturers more interested in research. Third, the stimulus factor in the form of research grant assistance program. More and more research grant programs offered will tend to encourage the quantity and quality of lecturer publications.

Based on data released by the Higher Education ITB ranks second after UGM. But in the aspect of research and publication ITB still excels from UGM. ITB occupies the first position for aspects of research and publication. The next question is what factors influence the quality and quantity of ITB lecturer research and publications. This is interesting to study. This article tries to reveal some of these factors.

\section{METHODS}

The study was conducted using a qualitative approach that aims to describe the conditions that exist in the situation. Data collection in this study was carried out through unstructured interview methods and documentation analysis. The results of interviews and documentation studies are then analyzed and outlined in the results of the study. The population of this study was conducted in the Bandung Institute of Technology. The sample was for the lecturers involved in the management of the Center for Science and Technology of the Microelectronics Center, one of the leading centers of Dikti Science and Technology in the field of microelectronics.

\section{RESULTS AND DISCUSSION}

Lecturers are important elements for the sustainability of higher education. Lecturers are professional educators and scientists with the main task of transforming, developing, and disseminating science, technology and art through education, research, and community service (paragraph 1 of the Teacher Law and Lecturer No 14 of 2015). Lecturers have a workload in the form of basic tasks and functions which are summarized in the form of Tri Darma of higher education which includes teaching / education, research and community service tasks. Tridharma Perguruan Tinggi, hereinafter referred to as Tridharma, is the obligation of Higher Education to carry out Education, research and community service (Law No. 12 of 2012). This is as stated in paragraph 1 of article 72 of the Law on Teachers and Lecturers No 14 of 2015 which states that the lecturer workload includes the main activities of planning learning, carrying out the learning process, evaluating learning, guiding and training, conducting research, carrying out additional tasks, and do community service.

As for what is meant by research, community service and learning as stated in the general provisions of Law No. 12 of 2012 are as follows. Research is an activity carried out according to the rules and scientific method systematically to obtain information, data and information relating to understanding and / or testing a branch of science and technology. Community Service is the activity of academicians who utilize Science and 
Technology to advance the welfare of the community and educate the lives of the nation. Learning is the process of interaction between students and lecturers and learning resources in a learning environment.

The main task of the lecturer in the field of teaching, research and community service requires a sustainable coaching program. For the education / teaching sector, every young lecturer is required to take the Instructional Technique Basic Skills Development Program (PEKERTI) and Applied Approach (AA) training. Both trainings are the basis for obtaining promotions and a number of other rights.

The research and community service program for young lecturers, so far has not been arranged in a systematic program. The tendency is only natural through personal coaching patterns from senior lecturers to young lecturers. The weakness of coaching factors in the field of research and community service needs to be addressed. One of the things that can be done is the establishment of a research center in the Institute for Research and Community Service.

A well institutionalized research culture can lead to a progressive positive culture from the lecturers. The pattern of the research host who is junior to senior researchers will produce a productive researcher regeneration pattern. The research host pattern can also be done by lecturers by empowering the potential of students both undergraduate and postgraduate students. Final level students have an obligation to conduct research and publication of research results.

The pattern of coaching young researchers from young lecturers and final level students will be optimal if the higher education research strategic plan is clear and focused. A clear research plan will generate a research roadmap that is programmed in the short, medium and long term. One of the problems that is often encountered in the pattern of lecturer research culture is that it is not clear what the lecturer research roadmap is.

The lack of clarity in the research roadmap can lead to several problems such as unsustainable research programs, difficulties in building science expertise, unproductive and unsustainable publications, promotion and class experience to slow down, and difficulties in applying functional positions to the chief lecturer and professor. The campus which has a clear research road map and each lecturer has a clear road map in accordance with the scientific field can improve the quality and quantity of research, publications and community service tend to be good. For example lecturers at ITB.

Based on data released by the DIKTI, ITB took second place after UGM. But in the aspect of research and publication ITB still excels from UGM. ITB occupies the first position for aspects of research and publication. The next question is what factors influence the quality and quantity of ITB lecturer research and publications. This is interesting to study.

Based on the information collected by the authors during the training on the Preparation of the Center for Excellence in Science and Technology in ITB, there was some information about academic culture, research, publications and community service that had been at ITB. First, from academic culture. Both lecturers and students at ITB have high standards in lectures. The standard in question is the lecture output standard. Because ITB mostly educates engineering bachelor candidates who are required to master the design and technology engineering in their fields, the level of lecture competence is directed at higher other thinking. Achievement of lower other thinking competencies has become a personal necessity for students to learn it.

Academic culture at the Bandung Institute of Technology is supported by several factors such as library facilities that provide many references needed in lectures. Second, the availability of laboratory facilities for lecture programs and lecture practicums. The Laboratium provided in such a way is made to the same standard or almost the same as the industry standard. Third, the ratio of lecturers and students in ITB based on data from forlap dikti ranges between 1: 6.3. A small ratio allows a more optimal pattern of academic guidance. All of these factors provide better opportunities for research hours for lecturers. As a comparison, the ratio of lecturers and students at State University of Malang in 2017 ranged from 1: 32.7, of course a very far comparison, as a result lecturers were tracked by the number of good teaching hours and the portion of time available for research became limited and narrow.

Furthermore, the factors that influence the culture of research and publication at ITB. First, the research roadmap is clear and always updated following the national innovation system. Awareness to compile a roadmap born from each lecturer personal. This cannot be separated from the experience of foreign studies of ITB lecturers. Overseas research cultures are trying to be implemented and have so far proven successful. Second, the portion of time outside of high teaching hours provides an opportunity to conduct optimal research. This is as mentioned above that the ideal ratio of the number of lecturers and students provides more research opportunities. Third, the umbrella research pattern is a systematic lecturer and student collaboration research.

The average ITB student research is part of the lecturer research collaboration. Thus each lecturer can increase the publication of his field of expertise along with guiding students' final assignments both undergraduate, master and doctoral programs. The empirical example that I present is what is done by the Chairman of the PUB PME ITB Dr. Trio Adiono, MT, every month is always published in international journals. This is monitored from the Google Scholition nitification. When traced to his publication both as first and second or third author.

The main researchers have on average a number of research assistants who are graduates of the master program that they have guided. After completion while waiting for work, the potential alumni were recruited as young researchers to conduct research in his laboratory. The model of coaching and involving young researchers gave birth to good mutualism. Senior research is helped in his research and young researchers 
are also helped to create research portfolios. It is useful both when going to work or continue their education.

\section{CONCLUSION}

Many factors influence the culture of research and the publication of lecturers in a college. One of the factors is the institutionalized and established research culture in the university environment. To build a positive research and publication culture, an institution in the form of a research center or a center of excellence in science and technology that can provide stimuli to lecturers to meet in collaborative research is needed. The next factor is the research fund assistance program provided by the institution. More and more periodically will encourage the willingness to do research. At the time of the many studies conducted by the lecturers, the publication will also increase. Publication culture can be done by making public media and facilities such as journals, conferences, seminars and others.

Collaborative patterns in research between senior researchers and junior researchers, or between potential lecturers and students and alumni can be done to improve the quality and quantity of research and publication of scientific works. Culture of research and publication of scientific works requires a conducive and systematic environment in the form of policies that support the flourishing of research. Every inhibiting factor needs to be minimized such as the number of teaching hours that are excess. Thus the ratio of the number of students and lecturers in universities needs to be made ideally so that the portion of time between teaching, research and community service can be normally distributed.

\section{REFERENCES}

[1] Kementerian Riset, Teknologi, dan Pendidikan Tinggi. 2017. Pangkalan Data Pendidikan Tinggi. Retrieved January 2, 2018, from https://forlap.ristekdikti.go.id/perguruantinggi/search.

[2] Kementerian Riset, Teknologi, dan Pendidikan Tinggi. 2017. 100 Besar Perguruan Tinggi Non Politeknik dan 25 Besar Perguruan Tinggi Politeknik di Indonesia Tahun 2017. Retrieved January 12, 2018, from https://ristekdikti.go.id/100-besar-perguruan-tinggi-nonpoliteknik-dan-25-besar-perguruan-tinggi-politeknik-diindonesia-tahun-2017.

[3] Pemerintah Republik Indonesia. 2005. Undang-undang Republik Indonesia Nomor 14 Tahun 2005 tentang Guru dan Dosen. 2015. Jakarta: Ministry of Ecudatioan and Culture.

[4] Pemerintah Republik Indonesia. 2005. Undang-undang Republik Indonesia Nomor 12 Tahun 2012 tentang Pendidikan Tinggi. 2015. Jakarta: Ministry of Ecudatioan and Culture.

[5] Pusat Mikroelektronika ITB. 2017. Strategi Membangun Indutri Elektronika Indonesia. Bandung: ITB Publising. 